\title{
The Winds of Change Continue
}

\author{
Patrick Fitch
}

$T_{1}$

wo years ago, in my first commentary as a member of the presidential team of the Canadian Society of Hospital Pharmacists (CSHP) (Can J Hosp Pharm. 2016;69[5]:432), I wrote about some of the changes that had occurred recently within our profession and the Society. I thought it would be timely, as I begin my final year as a member of the CSHP Executive, to revisit that theme. Significant changes are coming to CSHP, many of which will influence the direction of the Society in the future.

The biggest change is a transition in office leadership. After 15 years at the helm, CSHP's Executive Director, Myrella Roy, retired on December 31, 2018, and on January 2, 2019, Jody Ciufo officially took over as Chief Executive Officer. Jody brings a wealth of experience from the association management world and is looking forward to the challenge of leading CSHP in the years ahead.

You may be wondering why the Board decided to change the title of our most senior employee. When Myrella Roy announced her retirement, the Board agreed that this time of transition would be perfect to update CSHP's most senior manager's title. Historically, senior managers of not-for-profit organizations have held the title of "executive director". However, over the past 30 years or so, many organizations have changed the title to "chief executive officer", following a common business practice.

The current CSHP strategic plan is due to conclude in 2020, and work has already begun on the next strategic plan. The Board will meet in October 2019 for a full-day planning workshop. In advance of that meeting, the Board has committed to a strategic assessment of all of CSHP's programs and services, with 2 goals in mind: to inform the strategic planning process and to identify changes to programs and services that will strengthen CSHP as an organization.

The Internal Portfolio has also been busy. When we realized that we would not meet the membership targets set out in the current strategic plan, a working group of Board members, Branch presidents, and Membership Committee members was formed to develop recruitment and retention strategies. These strategies were approved by the Board in April 2018. Since then, the strategies have been prioritized, and additional work-

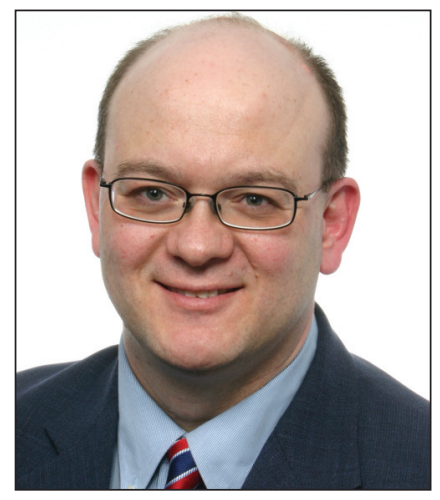
ing groups have been formed to develop implementation activities.

The future of the Professional Practice Conference has also undergone intense scrutiny by the Board, and a working group has been formed to identify how to revitalize the conference, now in its 50th year. Efforts are ongoing to evaluate all of CSHP's educational offerings, to discover the best ways to provide the high-quality education events that our members expect.

The awards program has also undergone a review, and changes have been recommended for both national and branch awards programs. The goal is to streamline awards offerings and avoid duplication.

As CSHP evaluates its programs and services, member input will be sought through various methods: surveys, polls, and social media. I encourage all members to make their views known when these opportunities arise.

I believe that exciting times are in store for CSHP, and I can't wait to see what lies ahead.

Patrick Fitch, BSP, ACPR, is Past President and Internal Liaison for the Canadian Society of Hospital Pharmacists. 